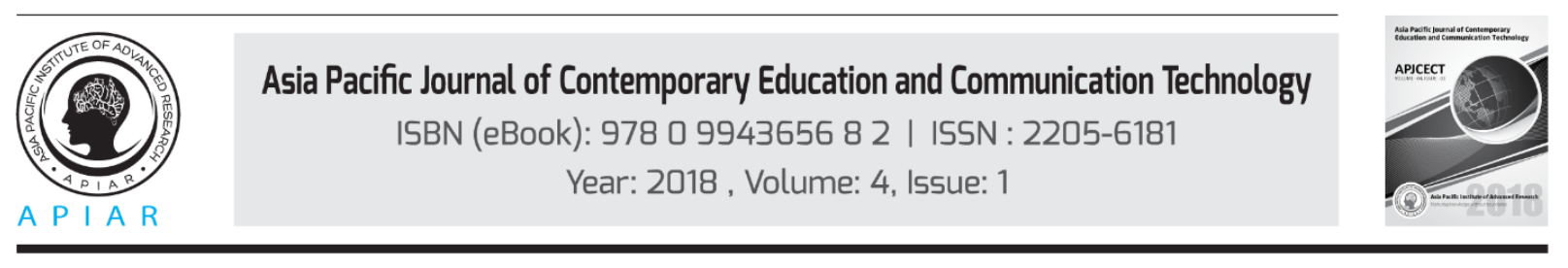

\title{
THE DEVELOPMENT OF POP-UP BOOK MEDIA TO IMPROVE 4th GRADE STUDENTS' LEARNING OUTCOMES OF CIVIC EDUCATION
}

\author{
Farid Ahmadi ${ }^{\mathrm{a}}$, Fakhruddin ${ }^{\mathrm{b}}$, Trimurtini $^{\mathrm{c}}$, Khafidhotul Khasanah ${ }^{\mathrm{d}}$ \\ abcd Faculty of Education Semarang State University, Indonesia \\ Corresponding email: farid@mail.unnes.ac.id
}

\begin{abstract}
Based on the result of the interview, there was no effective media to learn civic education about globalization. The problems in this research were to know the development procedure of popup book media, the feasibility and the effectiveness of it. This research aimed to develop popup book media about Globalization and to find out the feasibility and effectiveness of it to improve $4^{\text {th }}$ grade students' learning outcomes of civic education. This research was based on research and development (R\&D). Data was collected by interview, questionnaires and documentation. Analysis of data in this research used the descriptive quantitative method. The validation result showed that pop-up book media was feasible to use with score percentage from material expert $93.1 \%$ and score percentage from media expert $92.74 \%$. After the use of pop-up book media, there was an improvement of students' learning outcomes with N-Gain value 0.41 . In addition, $\mathrm{t}_{\text {score }}$ value was -22.833 with $\mathrm{Sig}$. (2-tailed) value $0.00<0.05$ which indicatedthat $\mathrm{Ha}$ was accepted because there was a significant difference between civic education learning outcome before using pop-up book media and after using it. In conclusion, pop-up book media was effective to improve students' learning outcomes of civic education.
\end{abstract}

Keywords: Civic Education; Pop-up Book; Learning Outcome.

\section{Introduction}

Education has strong impact on the development of a country. Education is an important aspect to develop the attitudes, knowledge, and skills needed for students in the life of society, nationality, and country. National education is education based on Pancasila and The Constitution of the Republic of Indonesia Year 1945 based on religious values, national culture of Indonesia and responsiveness to the demands of the changing times (Sisdiknas, 2003, p. 2). Therefore, every child is required to get education in order to increase their potentiality as a provision to face the various demands of the times, especially in the era of globalization. School as a formal institution of education, especially in elementary school, has an important role of building a foundation of positive character. One of the steps that could be taken to instill students' positive character is through Civic Education' subjects.

However, in reality, there are Civic Education' learning problems in schools. In the Academic Paper Policy Curriculum Review of Civic Education's subjects/Kebijakan Kurikulum \& KewarganegaraanTahun, (2007), there have been found some problem in the Standard Content' implementation of Civic Education subjects in elementary school such the scope of Basic Competition is larger than Standard, there are incorrect terms in scientific concepts, and the formulation of $\mathrm{KD}$ is considered too difficult for students. 
In addition, the use of media that is suitable with the content of material was not yet optimal so it impacted on the low students' learning outcomes, as it happened in Elementary School Tambakaji 01 Semarang. Documentation data showed that $4^{\text {th }}$ grade class students' learning outcomes of Civic Education was still low where there were 21 out of 38 students (55.3\%) completed learning, while 17 students have failed $(44.7 \%)$ by gotten score below 65 of Minimum Completed Learning Criteria.

Based on the interview result conducted by researcher with $4^{\text {th }}$ grade $B$ teacher, the information were obtained including: (1)Civic Education' subjects was difficult to understand because of the extensive and abstract concept material; (2) Students had difficulties in understanding the material, especially on the concept that contains values and behaviors that made students tend to memorize more than understand the material; (3) Teacher used textbooks in the form of Electronic School Books (BSE) with limited number (one book used for two students) as the main learning sources for students because of the school' limited infrastructure and facilities; and (4) teacher have not optimal on using various learning media of Civic Education' that made students' lack of interest to learn the material.

Civic Education's learning media is a selected learning media which is adjusted to the content and goal of Civic Education's learning subjects. Two main functions of learning media: learning media is used as a tool to understand the difficulty on understanding the material and learning media as a learning' source to increase students' learning experience so it can improve the quality of learning (Ruminiati, 2006, p. 2-11). Therefore, teachers should have been skilled in preparing lessons, as well as developing and using innovative Civic Education learning' media.

Media development is an effort to arrange learning media program which is more focused on media planning. Media that will be displayed or used in teaching and the learning process was first planned and designed in accordance with the needs of students (Musfiqon, 2011, p. 162).Pop-up books are included in the characteristics of a three-dimensional learning media, as the same group as media without projection which it presentations are visually three dimensional, that can be formed as the original object and also can be tangible which represents the original form (Daryanto, 2013, p. 29). Therefore, pop-up book include daunique and interesting learning media to help students understand the material that had been taught.

Pop-ups or movable books are three-dimensional books containing pieces of paper that appear or move when the book is opened and fully folded when the book is closed (Conrado, 2014). The ones that can make pop-ups appear are various methods of cutting and folding, as well as on the hidden mechanisms behind and under the page (Van, 2011, p. 19). The study of pop-up book media development in this study is supported by research conducted earlier by Scolastika Mariani (2014) in the International Journal of Education and Research. The results showed that PBL-assisted Pop-up Books Mathematics was effective against spatial abilities in class $8^{\text {th }}$ on geometric material.

The problem in this research is how to develop pop-up book media for Civic Education's learning that prove to be effective to improve students' learning outcomes. This study aims to develop a pop-up book media about globalization, as well as knowing the feasibility and effectiveness of the pop-up book media about globalization in improving $4^{\text {th }}$ grade students' learning outcomes of Elementary School Tambakaji o1 Semarang. 


\section{Research Method}

The research method that used in this research is a research and development (R\&D) method that can be interpreted as a scientific way to research, design, produce and test the validity of products that have been produced (Sugiyono, 2015, p. 30) . The research model used in this research is the Borg and Gall model that is adjusted to the scope of the research.

If you plan to do an R\&D education for the final project, the best thing to do is to undertake a small-scale project that involves a limited amount of original instructional design. Another way to scale down the project is to limit development to just a few steps of the R\&D cycle(Borg and Gall, 1983, p. 792). Here are 5 out of 10 steps of the R\&D cycle by Borg and Gall which used in this study: a) research and information collection, b) planning, c) development of preliminary form of product, d) preliminary field test, and e) main product revisions.

The Subjects in this study are $4^{\text {th }}$ grade students of Elementary School Tambakaji o1 Semarang. Data collection techniques in this study using interviews, questionnaires, documentation, and tests. Questionnaires used consisted of questions regarding media needs by teachers and students, questionnaire media assessment by media and material experts to test the feasibility of media, and questionnaire responses about pop-up book media by teacher and students. Data analysis techniques in this study using descriptive quantitative and qualitative techniques.

The effectiveness of pop-up book media was measured using students' learning outcomes. To determine the effectiveness of the pop-up book media, it was necessary to conduct pretest and posttest. The experimental design is done in the small-scale feasibility test using preexperimental design in the form of one-group pretest-posttest design so that the treatment result can be more accurate. Description of the result of the pretest is conducted to determine the students' learning outcomes before using pop-up book media while the description of the result of posttest is conducted to determine the students' learning outcomes after using pop-up book media. The effectiveness media to improve students' learning outcomes were examined based on the normalized gain or N-gain (Lestari, 2015) between pretest and posttest. Formulation of N-gain according to Lestari (2015), that is:

$$
\mathrm{N}-\text { Gain }=\frac{\text { PostestScore }- \text { PretestScore }}{\text { SMI }(\text { ScoreMinimumIdeal })-\text { PretestScore }}
$$

Furthermore, it was descriptively analyzed of $\mathrm{N}$-gain using $\mathrm{N}$-gain criterion according to Lestari (2015), namely: (1) learning outcomes with "high gain" if N-gain $\geq 0.7$; (2) learning outcomes with "medium gain" if $0.30<\mathrm{N}$-gain < 0.7; (3) learning outcomes with "low gain" if $\mathrm{N}$-gain $\leq 0.30$.

In addition, paired t-test was used to determine the significance of students' learning outcomes improvement on Civic Education. Data analysis technique of paired t-test was conducted using Statistical Package for Social Sciences (SPSS) software. Normality testing of the data was used Shapiro-Wilk test (Wahyudin, 2015). Had the data number/sample that been analyzed less than $50(n<50)$, would Shapiro-wilk have a higher level of accuracy than Kolmogorov-Smirnov Z.

\section{Result and Discussion}

The results and discussion presented in this section include: (1) the development of pop-up book media; (2) The feasibility of pop-up book media; and (3) The effectiveness of pop-up book media about Globalization. 


\subsection{The Development of Pop-up Book Media About Globalization}

The development of pop-up book media in this study starts with analyzing media which is needed by teachers and students using a questionnaire of needs. The criteria used in the questionnaire include: (1) responses to the learning of globalization material, (2) the requirements of pop-up book media about globalization, and (3) globalization material in the pop-up book. The result of requirement analysis was not fully selected by the researcher, but was adapted with the student's needs and the researcher's purpose in making the media and according to the prototype media that have been made.

The process of making the pop-up book is done through several stages: 1) planning stage (including the selection of materials referring to $\mathrm{SK}, \mathrm{KD}$, Indicator, and $4^{\text {th }}$ grade Civic Education' textbook on second semester); 2) determine the image of the figure and the material supporting image; 3) determine the techniques or pop-up elements; 4) create a prototype of pop-up book media "Indonesian Culture in International Cultural Mission"; 5) create a pop-up book design using Corel Draw and Photoshop programs based on the prototype that has been created; 6) print media designs using ivory 230 and ivory 260 paper which selected so the pop-up book media do not torn easily and make it easy to create shapes with certain pop-up techniques; 7) cutting the printed media using scissors and cutter according to the media design; 8) attach and compile the pop-up piece per pieces based on selected pop-up technique, then glued together using double tip; 9) merge page with another page using double tip and then bind the book by making hard-cover.

\subsection{The Feasibility of Pop-up Book Media About Globalization}

The pop-up book "Indonesian Culture in International Cultural Mission" that has been completed, need to be tested in terms of feasibility through expert validation test by material expert and media expert, as well as the feasibility test on small-scale use. Media assessment by material expert was conducted by STW as a lecturer of Civic Education' course and media assessment conducted by media expert SM, as a lecturer of Learning Media' course at the Elementary School Teacher Education Program, Faculty of Education, Semarang State University. The validator's media feasibility assessment instrument developed according to the theory of media development by Sadiman (2010: 41) and BSNP (2006) which then validated by supervisor. Furthermore, the media validation instrument is ready to be used for collecting data. The following is the assessment of pop-up book media validation by the material expert.

Table1:Material Feasibility Validation Result

\begin{tabular}{|c|c|c|c|}
\hline $\begin{array}{l}\text { Ass } \\
\text { con }\end{array}$ & $\begin{array}{l}\text { Assessment } \\
\text { content }\end{array}$ & Score & $\begin{array}{l}\text { Percentage } \\
\text { (P) }\end{array}$ \\
\hline \multicolumn{2}{|c|}{ 1. Content feasibility } & 42 & $95 \cdot 45 \%$ \\
\hline \multicolumn{2}{|c|}{$\begin{array}{l}\text { 2. Representation } \\
\text { feasibility }\end{array}$} & 11 & $91.67 \%$ \\
\hline \multicolumn{2}{|c|}{$\begin{array}{l}\text { 3. Contextual } \\
\text { Assessment }\end{array}$} & 10 & $83.33 \%$ \\
\hline \multicolumn{2}{|c|}{ 4. Language Assessment } & 45 & $93.75 \%$ \\
\hline \multicolumn{2}{|l|}{ Sum } & 108 & $364.20 \%$ \\
\hline $\begin{array}{l}\text { Total } \\
\text { Score }\end{array}$ & Instrument & 116 & - \\
\hline $\begin{array}{l}\text { Average } \\
\left(\mathbf{M}_{\mathbf{x}}\right)\end{array}$ & Percentage & - & $91.05 \%$ \\
\hline $\begin{array}{l}\text { Material } \\
\text { Criteria }\end{array}$ & Feasibility & Very $f$ & asible \\
\hline
\end{tabular}


Besides giving assessment, material expert also gives suggestion in helping to improve "Indonesian Culture in International Cultural Mission" pop-up book media which includes: (a)add local dance of Central Java and other islands in Indonesia for local dance material; (B) add another regional musical instruments, not just angklung and gamelan. Here is the validation assessment result by media expert on "Indonesian Culture in International Cultural Mission" pop-up book media.

Table 2: Media Feasibility Validation Result

\begin{tabular}{lll}
\hline $\begin{array}{l}\text { No. Assessment } \\
\text { content }\end{array}$ & Score & $\begin{array}{l}\text { Percentage } \\
(\mathbf{P})\end{array}$ \\
\hline 1. Form Feasibility & 8 & $100 \%$ \\
2. Design Feasibility & 56 & $82.35 \%$ \\
3. Media Feasibility & 51 & $91.07 \%$ \\
Sum & 115 & $273.42 \%$ \\
Total Instrument & 124 & - \\
$\begin{array}{l}\text { Score } \\
\text { Average Percentage } \\
\text { (Mx) }\end{array}$ & - & $91.14 \%$ \\
$\begin{array}{l}\text { Media Feasibility } \\
\text { Criteria }\end{array}$ & Very feasible \\
\hline
\end{tabular}

Besides giving assessment, media expert was also giving suggestion in helping to improve "Indonesian Culture in International Cultural Mission" pop-up book media which includes: (a) improve the back cover page, (b) improve the appearance at material pages of gamelan and wayang, and c) Add batik pictures' description on batik material page, d) Add picture which represent Indonesian group culture on international cultural events for page 6.

The next step is doing preliminary field test to obtain an initial qualitative evaluation of the new product (Borg and Gall, 1983, p. 782). The evaluation of preliminary field test in this research is carried out as a trial feasibility in small-scale class that was conducted by 6 students of $4^{\text {th }}$ A grade class of Elementary School Tambakaji o1 Semarang who chose heterogeneously. In the trial feasibility, students were asked to give their responses after using pop-up book media on responsive questionnaires covering material, language, and interest aspects. The average acquisition percentage of student responses on a small-scale test to media was 91.15\% with a very good category. After the trial feasibility, all data were compiled and analyzed. The researcher used these results to plan the revision and then went on to make the revisions called for. Media that had been improved then ready for trial effectiveness on this research subjects.

\subsection{The Effectiveness of Pop-Up Book Media about Globalization}

Media effectiveness test is conducted on a small scale and large scale class using pop-up book media "Indonesian Culture and International Culture Mission". Students' learning outcomes can be said to increase if the acquisition value of $\mathrm{N}$-gain $\geq 0.3$ (Lestari, 2015: 235). This is the learning outcomes from the media feasibility test on small-scale class.

Table 3:Media effectiveness Result on Small-scale Class

\begin{tabular}{|c|c|c|c|}
\hline No. & Description & $\begin{array}{l}\text { Learnir } \\
\text { outcom } \\
\text { Pretest }\end{array}$ & Posttest \\
\hline 1. $\mathrm{I}$ & of students & 6 & 6 \\
\hline 2. $A$ & score & 45 & 70 \\
\hline
\end{tabular}




\begin{tabular}{lll} 
3. Maximum score & 65 & 85 \\
4. Minimum score & 35 & 50 \\
5. Number of completed & 1 & 5 \\
students & & \\
$\begin{array}{l}\text { 6. Number of uncompleted } \\
\text { students }\end{array}$ & 5 & 1 \\
$\begin{array}{l}\text { Average of Classical } \\
\text { KKM }\end{array}$ & $16.7 \%$ & $83.3 \%$ \\
Improvement (N-Gain) & 0.45 & \\
\hline
\end{tabular}

Based on the result data analysis, it showed that the use of pop-up book media "Indonesian Culture in International Cultural Mission" can improve the learning outcomes of small-scale students with the percentage of mastery learning $83.3 \%$ so it can be concluded that the pop-up book media effectively improve the students' learning outcomes.

Furthermore, on the large scale classroom effectiveness test on 38 students in $4^{\text {th }}$ A grade student's of Elementary School Tambakaji o1 Semarang pretest is conducted after using pictures as media that have been used by teacher while posttest is conducted after using popup book media that have been revised. This is the analysis result of large-scale effectiveness test.

\begin{tabular}{|c|c|c|}
\hline \multirow[t]{2}{*}{ No. $\quad$ Description } & \multicolumn{2}{|c|}{$\begin{array}{l}\text { Learning } \\
\text { outcomes }\end{array}$} \\
\hline & Pretest & Posttest \\
\hline 7. Number of students & 38 & 38 \\
\hline 8. Average score & 58.8 & $75 \cdot 4$ \\
\hline 9. Maximum score & 75 & 90 \\
\hline Minimum score & 35 & 50 \\
\hline $\begin{array}{l}\text { 11. Number of completed } \\
\text { students }\end{array}$ & 12 & 36 \\
\hline $\begin{array}{l}\text { 12. Number of uncompleted } \\
\text { students }\end{array}$ & 26 & 4 \\
\hline $\begin{array}{l}\text { Average of Classical } \\
\text { KKM }\end{array}$ & $31.6 \%$ & $94.7 \%$ \\
\hline Improvement (N-Gain) & 0.41 & \\
\hline
\end{tabular}

Based on the data analysis, it can be concluded that "Indonesian Culture in International Culture Mission" pop-up book media is effective to improve learning outcomes with the percentage of mastery learning $94.7 \%$ in $4^{\text {th }}$ A grade student's of Elementary School Tambakaji o1 Semarang. The improvement of learning outcomes on media effectiveness test can be seen in the following diagram. 


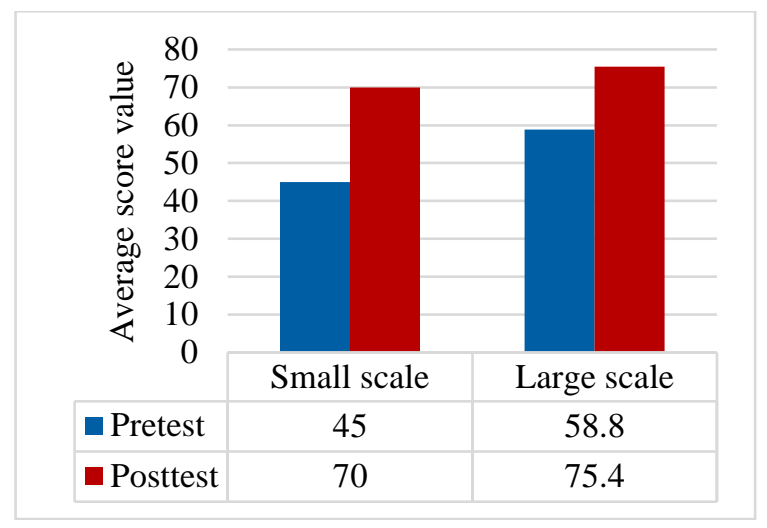

Figure 7: The Improvement of Small and Large Scale Class' Learning Outcomes

In addition, Teacher and students on the test of media effectiveness and test of pop-up book media in large-scale classrooms, giving response questionnaires after using pop-up book. As for the acquisition of percentage of teacher response to media, it was87.5\% while student responses were $84.50 \%$ in very good category.

Furthermore, calculation result of t-test obtained t-test of two dependent samples results $t_{\text {count }}$ value was -22.833 with Sig. (2-tailed) value $0.00<0.05$ which indicated that Ha was accepted. So, it means that there is a significant difference between the results of learning Civic Education before using pop-up book media and after using it. With regard to this matter, it can be concluded that the development of pop-up book about Globalization is effective to improve students' learning outcomes of Civic Education. Here's the development of pop-up book media "Indonesian Culture in International Cultural Mission" views.

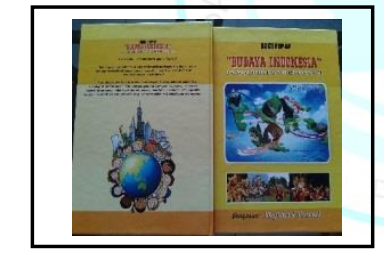

Picture 8. Cover

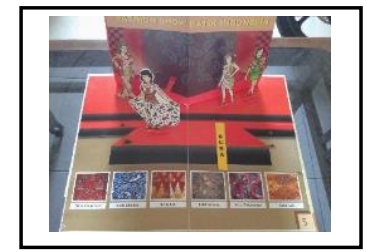

Picture 10. Batik

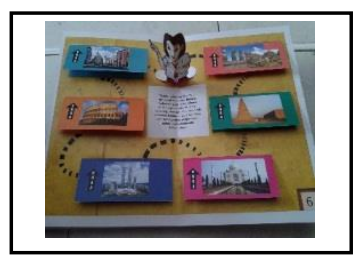

Picture 11. Indonesian group culture in internasional events

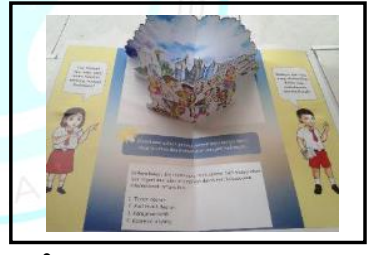

Picture 9.

The definition of globalization

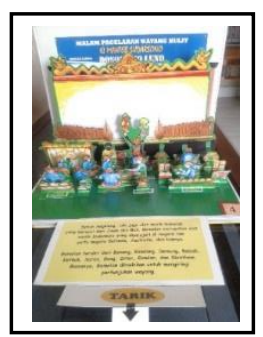

Picture 12.

Wayang and gamelan 


\section{Conclusion}

Based on the result of this research, it can be concluded that (1) this research produces a product in the form of a pop-up book entitled "Indonesian Culture in International Cultural Mission". The development process in this research adapts 5 out of 10 development stages of Borg and Gall (1983) which include a) research and information collection; b) planning; c) development of preliminary form of product; d) preliminary field test; and e) main product revisions,(2) validation result showed that pop-up book media was feasible to use with score percentage from material expert $93.1 \%$ and score percentage from media expert $92.74 \%$ in very feasible criteria with revisions while the students' responses questionnaire result showed

91.15\% with very good criteria, and (3) based on the media effectiveness test result, after using pop-up book media, there was an improvement of students' learning outcomes with N-Gain value 0.41 in medium criteria. In addition, tscorevalue was -22.833 with Sig. (2-tailed) value $0.00<0.05$ which means that $\mathrm{Ha}$ is accepted. So, it can be concluded that the development of pop-up book about Globalization is effective to improve $4^{\text {th }}$ grade students' learning outcomes of Civic Education.

\section{Acknowledgement}

The authors would like to thank the rector of Universitas Negeri Semarang, Dean of Education Faculty, and School Principal and classroom teacher of $4^{\text {th }}$ grade class of Elementary School Tambakaji 01 Semarang who helped and gave permission to conduct this research. 


\section{References}

i. $\quad$ Borg, Gall, W. R. d. \& Meredith, D., 1983. Educational Reaserch: An Introduction. New York: Longman.

ii. $\quad$ BSNP, 2006. Panduan Kurikulum Tingkat Satuan Pendidikan (KTSP).. Jakarta: BP. Dharma Bakti.

iii. Conrado, 2014. "Multi-style Paper Pop-up Designs from 3D Models". International Journal of Eurographics, 33(2).

iv. Dyk, V. \& Stephen, 2011. Paper Engineering: Fold, Pull \& Turn. Washington, DC: Smithsonian Institution.

v. KebijakanKurikulum, N. K. \& KewarganegaraanTahun, P., 2007. Nomor 22 Tahun 2006 tentangStandar Isi. Permendiknas RI: s.n.

vi. Mariani \& Scolastika, 2014. The Effectiveness of Learning by PBL Assisted Mathematics Pop Up Book Againts The Spatial Ability in Grade VIII on Geometry Subject Matter". International Journal of Education and Research, 2(8).

vii. Musfiqon, 2012. Pengembangan Media danSumberPembelajaran. Jakarta: PrestasiPustakaraya.

viii. Persada, G. \& Sugiyono., 2015. MetodePenelitiandanPengembangan. Bandung: Alfabeta.

ix. $\quad$ Sadiman \& Arief, 2010. Media Pendidikan PengertianPengembangandanPemanfaatannya.. Jakarta: P.T Raja. 